\title{
Wpływ wieku studentów kierunku pielęgniarstwo na nawyki psychiczne i nawyki prozdrowotne
}

\section{The nursing students' age impact on health-improving habits and mental attitude}

\author{
NATALIA PAWLAK ${ }^{1}$, IDA SZLACHCIAK ${ }^{1}$, ZUZANNA WALASIEWICZ1, \\ BEATA HAOR ${ }^{2}$
}

${ }^{1}$ Studenckie Koło Naukowe Nauk o Zdrowiu, Instytut Nauk o Zdrowiu PWSZ we Włocławku

${ }^{2}$ Instytut Nauk o Zdrowiu PWSZ we Włocławku

DOI: http://dx.doi.org/10.21784/lwP.2017.016

ISSN: 245-1846

\section{Streszczenie:}

Wstęp. Styl życia określa się jako indywidualny dla każdego człowieka zespół codziennych zachowań. Może on być ukształtowany przez warunki życia, czynniki kulturowe i cechy osobiste.

Cel badań. Celem podjętych badań było zweryfikowanie wpływu wieku studentów na kształtowanie się ich nawyków zdrowotnych i nastawienia psychicznego.

Materiał i metody. Badania zostały przeprowadzone wśród studentów I roku studiów pierwszego stopnia na kierunku pielęgniarstwo. Wykorzystano metodę sondażu diagnostycznego, metodę szacowania oraz technikę ankietowania i technikę skali szacunkowej. Narzędziem badawczym był Kwestionariusz Zachowań Zdrowotnych (IZZ) uzupełniony o autorską metryczkę. 
Wyniki. Zaprezentowane wyniki badań przedstawiają różnice w nastawieniu psychicznym i nawykach zdrowotnych studentów z uwagi na ich wiek.

Wnioski. Wiek nie wpływa istotnie na różnicę w zakresie nastawienia psychicznego i prezentowanych przez studentów nawykach zdrowotnych.

Słowa kluczowe: zachowania zdrowotne, styl życia, zdrowie

\section{Abstract:}

Introduction. Lifestyle is defined as a individual set of daily habits. It can be shaped by living conditions, cultural factors, and personal chracteristics /qualities.

Aim. The aim of this survey was to verify the impact of students' age on their health habits and psychological attitude.

Material and methods. A group of first year nursing students took part in the survey. The diagnostic method, the estimation method, survey technique as well as estimation technique were used.

Results. The results of the survey show differences in psychological attitude and health habits on grounds of age.

Conclusions. Students' age is not a significant factor influencing their psychological attitude and health habits.

Keywords: health habits, lifestyle, health

\section{Wstęp}

Styl życia to zakres i formy codziennych zachowań jednostek lub grup, specyficzne dla ich usytuowania społecznego, tzn. manifestujące położenie społeczne. Umożliwiają zatem szeroko rozumianą społeczną lokalizację innych ludzi. Pojęcie to obejmuje nie tylko zachowania ludzkie, ale i psychofizyczne mechanizmy leżące u ich podstaw: motywacje, potrzeby, akceptowane wartości [1].

Zachowania zdrowotne są to te zachowania, które w świetle współczesnej wiedzy medycznej wywołują określone - pozytywne lub negatywne - skutki zdrowotne u osób, które je realizują. Są to zarówno 
reakcje na wszelkie sytuacje związane ze zdrowiem jak i nawyki oraz celowe czynności [2]. Do zachowań prozdrowotnych można zaliczyć wszelkie nawyki i czynności stanowiące czynniki utrwalające i polepszające zdrowie. Źródłem ich są najczęściej postawy i wartości nabyte $\mathrm{w}$ rodzinie oraz najbliższym środowisku społecznym. Podstawowe kategorie zachowań prozdrowotnych związane są ze zdrowiem fizycznym, psychospołecznym, prewencją zdrowotną i unikaniem zachowań ryzykownych, szkodliwych [3]. Ważne jest zwrócenie uwagi na to, że człowieka ujmuje się jako całość biopsycho-społeczną, a każdy aspekt wpływa nierozerwalnie na całość ludzkiego funkcjonowania, $w$ tym na przykład na jego zdrowie. Typowe zachowania prozdrowotne to: aktywność fizyczna, racjonalne żywienie, hartowanie, dbanie o ciało i jego higienę, unikanie stresu jak i jego niepowodowanie, przestrzeganie zasad bezpieczeństwa w szkole, pracy, życiu codziennym i ruchu drogowym, unikanie ryzykownych zachowań seksualnych, niepalenie tytoniu, ograniczone używanie alkoholu i niezażywanie substancji psychoaktywnych [4]. Niektórzy badacze dodają do tego wizyty kontrolne u lekarzy i samokontrolę [5]. Zachowania antyzdrowotne to te zachowania człowieka, które w sposób bezpośredni lub pośredni wpływają na pogorszenie jego stanu zdrowia. Nie są podejmowane świadomie w celu samozniszczenia, ale taki mają skutek (choć niektóre są tylko wynikiem złych nawyków lub przyzwyczajeń nabywanych podczas procesów wychowania i socjalizacji) [6].

Pojęcie poczucia koherencji jest stosowane przede wszystkim w psychologii zdrowia, jako nazwa czynnika prewencyjnego dla zachowania zdrowia. Koherencja wewnętrzna to spójność, jednorodność spoistość zjawisk, procesów, poglądów itp. [7].Poczucie koherencji składa się ze zdolności zrozumienia wydarzeń, poczucia zaradności i poczucia sensowności podejmowania zaangażowania i kreowania własnego życia. Można wyróżnić następujące składowe koherencji: poczucie koherencji, poczucie zrozumiałości, poczucie zaradności; sterowalności, poczucie sensowności [8]. 
Celem pracy było analiza wpływu wieku studentów kierunku pielęgniarstwo na kształtowanie się ich nawyków zdrowotnych i nastawienia psychicznego.

\section{Materiał i metody}

Badania zostały przeprowadzone wśród studentów studiów pierwszego stopnia na kierunku pielęgniarstwo. Wykorzystano metodę sondażu diagnostycznego, metodę szacowania oraz technikę ankietowania i technikę skali szacunkowej. Narzędziem badawczym był kwestionariusz Inwentarza Zachowań Zdrowotnych (IZZ) składający się z 24 pytań. Uzupełniony on został o autorską metryczkę $\mathrm{z}$ danymi socjodemograficznymi respondentów. IZZ zakupiono w Pracowni Testów Psychologicznych Polskiego Towarzystwa Psychologicznego. Kwestionariusz obejmował zagadnienia związane z zachowaniami zdrowotnymi m.in. takimi jak: unikanie palenia tytoniu, przeziębień, jedzenie owoców i warzyw, spożywanie pełnoziarnistego pieczywa, preferowanie odpowiedniej ilości wypoczynku, snu, posiadanie przyjaciół, unikanie silnych emocji stresów [9].

Badania przeprowadzono wśród 43 studentów pierwszego roku studiów na kierunku pielęgniarstwo (studia pierwszego stopnia) w Państwowej Wyższej Szkole Zawodowej we Włocławku. Udział w badaniach był dobrowolny i anonimowy.

Opracowanie wyników badań z wykorzystaniem arkusza kalkulacyjnego przebiegało $\mathrm{w}$ kliku etapach. $\mathrm{W}$ pierwszym nastąpiła weryfikacja zebranych ankiet pod kątem kompletności oraz właściwego wypełnienia kwestionariuszy. Spośród rozprowadzonych 48 ankiet wyczerpujący materiał otrzymano od 43 osób. Z tego powodu do dalszych obliczeń wzięto pod uwagę tylko 43 kwestionariusze $\mathrm{z}$ kompletnymi odpowiedziami. Wskaźnik efektywności uzyskania danych wyniósł 89,6\%. 
Następnie przeanalizowano grupę badanych na podstawie zmiennych socjodemograficznych. W kolejnym etapie $\mathrm{w}$ celu dokładniejszej analizy cech mających wpływ na zachowania prozdrowotne porównano informacje zebrane o respondentach z ich odpowiedziami udzielonymi w kwestionariuszu IZZ. Dane przedstawiono w postaci tabel i wykresów. Na tej podstawie dokonano analizy statystycznej z wykorzystaniem liczebności respondentów, udziału procentowego, sumarycznej liczby punktów i średniej liczby punktów udzielonych na dane pytanie $\mathrm{z}$ uwzględnieniem zmiennych socjodemograficznych. Ostatnim etapem badania była analiza merytoryczna i interpretacja uzyskanych wyników.

Respondenci zostali podzieleni na pięć przedziałów wiekowych: 19-25, 26-30, 31-35, 36-40, 41 i więcej. W grupie badanych zdecydowaną większość stanowili studenci w przedziale wiekowym 19-25 lat $(65,1 \%)$. Najmniejszą grupę tworzyli respondenci powyżej 41 roku życia (2,3\%).

W badaniach wzięło udział 28 studentów z przedziału wiekowego $19-25$ lat $(65,1 \%$ badanych), 26-30 lat - 7 studentów (16,3\%), 31-35 lat - 4 studentów (9,3\%), 36-40 lat - 3 studentów $(7,0 \%)$ oraz 41 i więcej - 1 student $(2,3 \%)$. Rozkład próby ze względu na płeć przedstawiono na rycinie 1 .
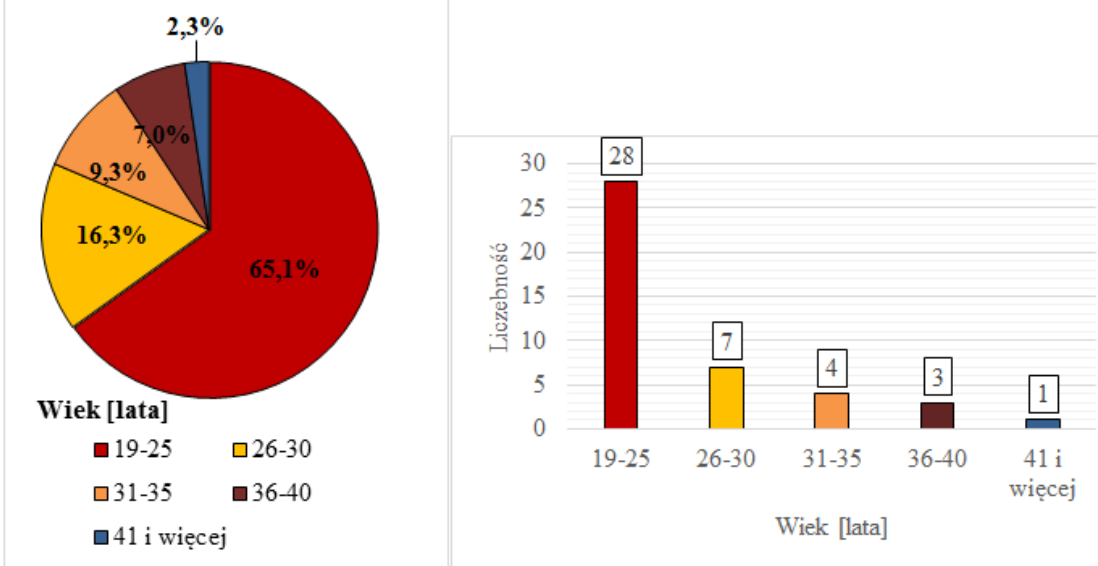
Rycina 1. Charakterystyka badanych ze względu na wiek.

Źródło: wynik badań własnych.

\section{Wyniki}

Zaprezentowane $\mathrm{w}$ opracowaniu wyniki wskazują na preferencje studentów w zakresie zachowań zdrowotnych, które kształtują obraz stylu życia.

Tabela 1 przedstawia charakterystykę zachowań zdrowotnych studentów w zakresie nastawienia psychicznego i nawyków prozdrowotnych ze względu na ich wiek.

Tabela 1. Nastawienie psychiczne i nawyki prozdrowotne badanych ze względu na wiek. 


\begin{tabular}{|c|c|c|c|c|c|c|c|c|c|c|c|c|c|}
\hline \multirow[t]{2}{*}{ Lp. } & \multirow[t]{2}{*}{ Pytanie } & \multirow{2}{*}{$\begin{array}{c}\text { Sumary } \\
\text { czna } \\
\text { 1.pkt za } \\
\text { pytanie }\end{array}$} & \multirow{2}{*}{$\begin{array}{c}\text { Srednia } \\
\text { 1. pkt } \\
\text { za } \\
\text { pytanie }\end{array}$} & \multicolumn{5}{|c|}{ Suma dla wieku } & \multicolumn{5}{|c|}{ Średnia dla wieku } \\
\hline & & & & ๙̃ & 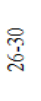 & $\frac{n}{m}$ & 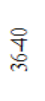 & 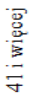 & ๙̃ & 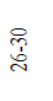 & $\frac{m}{m}$ & 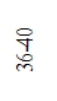 & 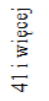 \\
\hline 3 & $\begin{array}{c}\text { Poważnie } \\
\text { traktuję } \\
\text { wskazówki osób }\end{array}$ & 147 & 3,42 & 95 & 27 & 14 & 9 & 2 & 3,39 & 3,86 & 3,50 & 3,00 & 2,00 \\
\hline 7 & $\begin{array}{c}\text { Unikam } \\
\text { sytuacji, które } \\
\text { wpływają na } \\
\text { mnie } \\
\text { przygnębiająco }\end{array}$ & 128 & 2,98 & 82 & 21 & 12 & 9 & 4 & 2,93 & 3,00 & 3,00 & 3,00 & 4,00 \\
\hline 11 & $\begin{array}{c}\text { Staram siẹ } \\
\text { unikać zbyt } \\
\text { silnych emocji, } \\
\text { stresów i napięć }\end{array}$ & 113 & 2,63 & 72 & 19 & 9 & 8 & 5 & 2,57 & 2,71 & 2,25 & 2,67 & 5,00 \\
\hline 15 & $\begin{array}{l}\text { Mam przyjaciół } \\
\text { i uregulowane } \\
\text { życie rodzinne }\end{array}$ & 184 & 4,28 & $\begin{array}{c}11 \\
9\end{array}$ & 31 & 16 & 13 & 5 & 4,25 & 4,43 & 4,00 & 4,33 & 5,00 \\
\hline 19 & $\begin{array}{l}\text { Unikam takich } \\
\text { uczuć, jak } \\
\text { gniew, lẹk i } \\
\text { depresja }\end{array}$ & 122 & 2,84 & 74 & 21 & 13 & 9 & 5 & 2,64 & 3,00 & 3,25 & 3,00 & 5,00 \\
\hline 23 & $\begin{array}{c}\text { Myślę } \\
\text { pozytywnie }\end{array}$ & 144 & 3,35 & 74 & 23 & 14 & 10 & 5 & 3,29 & 3,29 & 3,50 & 3,33 & 5,00 \\
\hline 4 & $\begin{array}{l}\text { Wystarczająco } \\
\text { dużo } \\
\text { odpoczywam }\end{array}$ & 95 & 2,21 & 64 & 16 & 6 & 8 & 1 & 2,29 & 2,29 & 1,50 & 2,67 & 1,00 \\
\hline 8 & $\begin{array}{c}\text { Unikam } \\
\text { przepracowania }\end{array}$ & 99 & 2,30 & 68 & 14 & 8 & 8 & 1 & 2,43 & 2,00 & 2,00 & 2,67 & 1,00 \\
\hline 12 & $\begin{array}{l}\text { Kontroluję } \\
\text { swoją wagę } \\
\text { ciała }\end{array}$ & 127 & 2,95 & 84 & 20 & 11 & 10 & 2 & $\begin{array}{c}3,0 \\
0\end{array}$ & $\begin{array}{c}2,8 \\
6\end{array}$ & $\begin{array}{c}2,7 \\
5\end{array}$ & $\begin{array}{c}3,3 \\
3\end{array}$ & $\begin{array}{c}2,0 \\
0\end{array}$ \\
\hline 16 & $\begin{array}{c}\text { Wystarczająco } \\
\text { dużo śpię }\end{array}$ & 100 & 2,33 & 67 & 15 & 7 & 9 & 2 & $\begin{array}{c}2,3 \\
9\end{array}$ & $\begin{array}{c}2,1 \\
4\end{array}$ & $\begin{array}{c}1,7 \\
5\end{array}$ & $\begin{array}{c}3,0 \\
0\end{array}$ & $\begin{array}{c}2,0 \\
0\end{array}$ \\
\hline 20 & $\begin{array}{c}\text { Ograniczam } \\
\text { palenie tytoniu }\end{array}$ & 179 & 4,16 & $\begin{array}{c}11 \\
4\end{array}$ & 25 & 20 & 15 & 5 & $\begin{array}{c}4,0 \\
7\end{array}$ & $\begin{array}{c}3,5 \\
7\end{array}$ & $\begin{array}{c}5,0 \\
0\end{array}$ & $\begin{array}{c}5,0 \\
0\end{array}$ & $\begin{array}{c}5,0 \\
0\end{array}$ \\
\hline 24 & $\begin{array}{c}\text { Unikam } \\
\text { nadmiernego } \\
\text { wysiłku } \\
\text { fizycznego }\end{array}$ & 124 & 2,88 & 80 & 20 & 11 & 9 & 4 & $\begin{array}{c}2,8 \\
6\end{array}$ & $\begin{array}{c}2,8 \\
6\end{array}$ & $\begin{array}{c}2,7 \\
5\end{array}$ & $\begin{array}{c}3,0 \\
0\end{array}$ & $\begin{array}{c}4,0 \\
0\end{array}$ \\
\hline
\end{tabular}

Źródło: wynik badań własnych.

Jak wynika $\mathrm{z}$ danych zaprezentowanych $\mathrm{w}$ tabeli 1 niezależnie od wieku najwyższą liczbę punktów uzyskiwali respondenci 
potwierdzając preferowanie takich zachowań zdrowotnych jak: posiadanie przyjaciół i uregulowanego życia rodzinnego (184 pkt. średnia liczba pkt. - 4,28), ograniczanie palenia (179 pkt. - średnia liczba pkt. 4,16). Najniższą liczbę punktów studenci otrzymali za wdrażanie takich zachowań zdrowotnych jak: wystarczająco długie odpoczywanie (95 pkt. - średnia liczba pkt. 2,21), unikanie przepracowania (99 pkt. - średnia liczba pkt. 2,30).

Najwyższą średnią liczbę punktów uzyskali badani z przedziału wiekowego 41 lat i więcej oraz 26-30 lat prezentując takie zachowania zdrowotne jak: „mam przyjaciół i uregulowane życie rodzinne”, „ograniczam palenie tytoniu”. Najniższą średnią liczbę punktów w tym zakresie uzyskali respondenci w wieku 31-35 lat oraz 26-30 lat.

W tabeli 2 przedstawiono średnią liczbę punktów uzyskanych przez badanych w kategorii nastawienie psychiczne.

Tabela 2. Średnia liczba punktów uzyskanych przez badanych w kategorii nastawienie psychiczne. 


\begin{tabular}{|c|c|c|c|c|c|c|}
\hline Kategoria & \multicolumn{6}{|c|}{ Nastawienie psychiczne } \\
\hline Nr pytania & 3 & 7 & 11 & 15 & 19 & 23 \\
\hline $\begin{array}{c}\text { Treść } \\
\text { pytania }\end{array}$ & $\begin{array}{c}\text { Poważnie } \\
\text { traktuję } \\
\text { wskazówki } \\
\text { osób }\end{array}$ & $\begin{array}{c}\text { Unikam } \\
\text { sytuacji, które } \\
\text { wpływają na } \\
\text { mnie } \\
\text { przygnębiająco }\end{array}$ & $\begin{array}{c}\text { Staram się } \\
\text { unikać zbyt } \\
\text { silnych } \\
\text { emocji, } \\
\text { stresów i } \\
\text { napiẹć }\end{array}$ & $\begin{array}{c}\text { Mam } \\
\text { przyjaciół i } \\
\text { uregulowane } \\
\text { życie } \\
\text { rodzinne }\end{array}$ & $\begin{array}{c}\text { Unikam } \\
\text { takich } \\
\text { uczuć, jak } \\
\text { gniew, lẹk i } \\
\text { depresja }\end{array}$ & $\begin{array}{c}\text { Myślę } \\
\text { pozytywnie }\end{array}$ \\
\hline Wiek [lata] & \multicolumn{6}{|c|}{ Średnia liczba punktów } \\
\hline $19-25$ & 3,39 & 2,93 & 2,57 & 4,25 & 2,64 & 3,29 \\
\hline $26-30$ & 3,86 & 3,00 & 2,71 & 4,43 & 3,00 & 3,29 \\
\hline $31-35$ & 3,50 & 3,00 & 2,25 & 4,00 & 3,25 & 3,50 \\
\hline $36-40$ & 3,00 & 3,00 & 2,67 & 4,33 & 3,00 & 3,33 \\
\hline $41 \mathrm{i}$ wiecej & 2,00 & 4,00 & 5,00 & 5,00 & 5,00 & 5,00 \\
\hline
\end{tabular}

Źródło: wynik badań własnych.

Jak wynika $\mathrm{z}$ tabeli $2 \mathrm{w}$ kategorii nastawienie psychiczne najwyższą średnią liczbę punktów respondenci, niezależnie od wieku, uzyskali preferując takie zachowania zdrowotne jak posiadanie przyjaciół i uregulowanego życia rodzinnego. Natomiast najniższą średnią liczbę punktów studenci otrzymali za wdrażanie takich zachowań jak unikanie zbyt silnych emocji, stresów i napięć.

Analizę preferencji respondentów (z uwzględnieniem przedziałów wiekowych) w zakresie posiadania przyjaciół i uregulowanego życia rodzinnego przedstawia rycina 2 . 


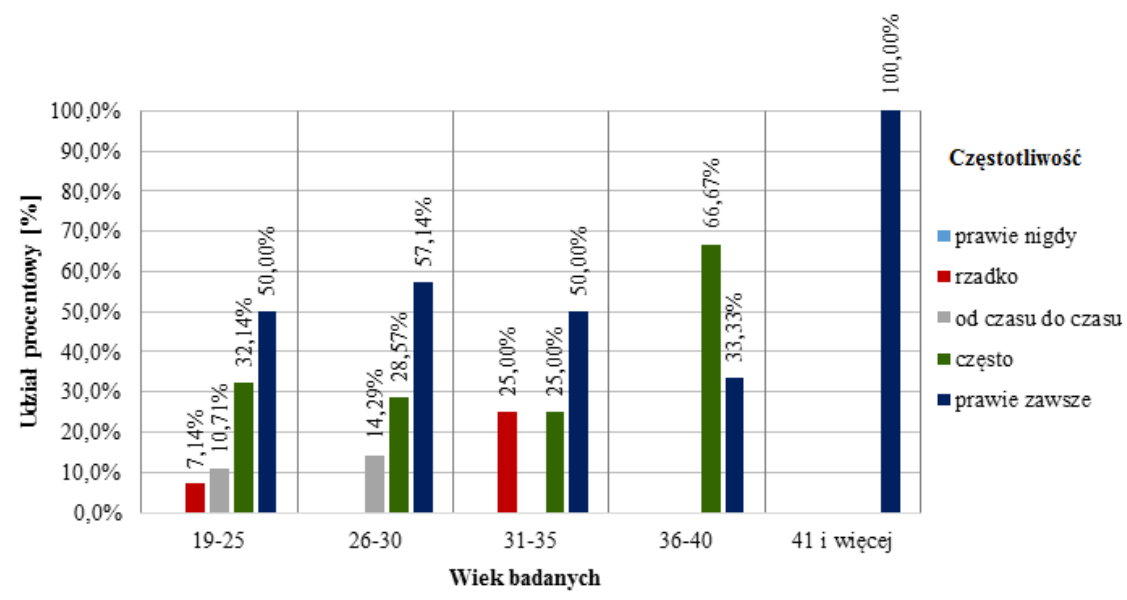

Rycina 2. Posiadanie przyjaciół i uregulowanego życia rodzinnego przez badanych w zależności od ich wieku.

Źródło: wynik badań własnych.

Jak wynika $\mathrm{z}$ ryciny 2 największe zróżnicowanie zaobserwowano $\mathrm{w}$ odpowiedziach studentów $\mathrm{w}$ przedziale wiekowym 19-25 lat. Połowa respondentów z przedziału wiekowego 19-25 lat (50\%) prawie zawsze wykazuje posiadanie przyjaciół i uregulowanego życia rodzinnego. Potwierdza to także większość studentów w wieku 26-30 lat $(57,14 \%)$, z przedziału wiekowego 3135 lat $(50,0 \%)$ oraz 36-40 lat (66,67\%). Najmniejszą różnorodność w odpowiedziach odnotowano u studentów w przedziale wiekowym 41 lat i więcej ze względu na bardzo małą liczebność grupy - 1 osoba (100\%). Zdecydowana większość badanych niezależnie od wieku podkreśla, że prawie zawsze lub często posiada przyjaciół i uregulowane życie rodzinne.

Analizę preferencji respondentów $\mathrm{z}$ uwzględnieniem przedziałów wiekowych w zakresie unikania silnych emocji, stresów i napięć przez badanych przedstawia rycina 3 . 


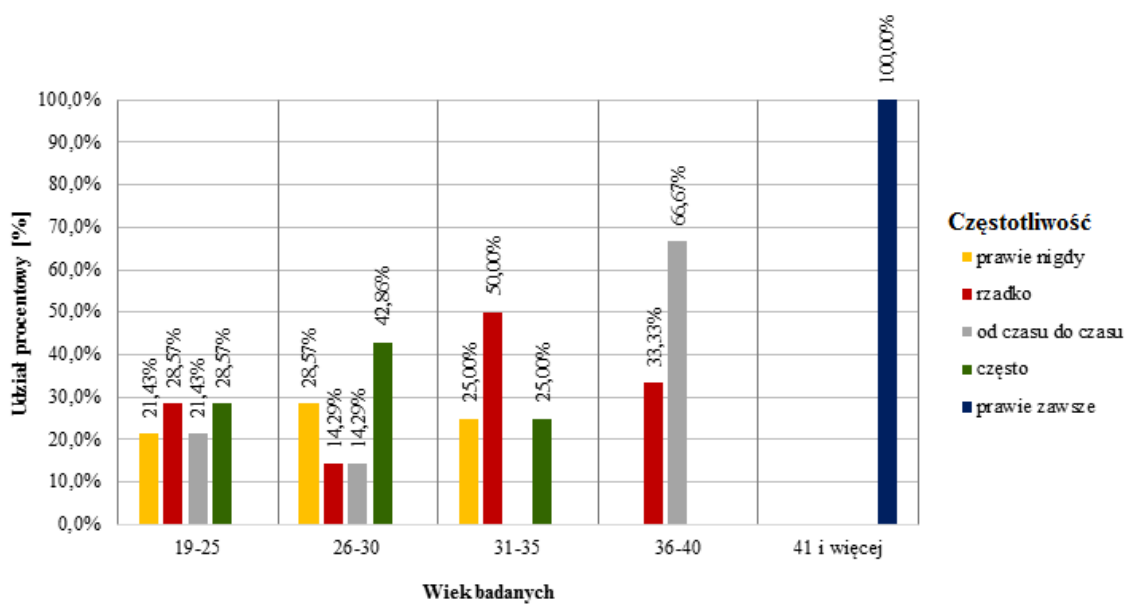

Rycina 3. Unikanie zbyt silnych emocji, stresów i napięć przez badanych w zależności od ich wieku.

Źródło: wynik badań własnych.

W przedziale wiekowym 19-25 lat studenci rzadko (28,57\%) lub często $(28,57 \%)$ unikają zbyt silnych emocji, stresów i napięć. Respondenci w wieku 36-30 lat najczęściej wskazywali, że udaje to im często $(42,8 \%)$ a w wieku $31-35$ lat połowa badanych $(50,0 \%)$ podała, że zdarza się to rzadko. Natomiast większość studentów w wieku 3640 lat $(66,67 \%)$ wskazała, że udaje się im to od czasu do czasu. Najstarszy respondent $\mathrm{w}$ wieku 41 lat i więcej podał, że zdarza się to prawie zawsze (1 osoba - 100\%). Unikanie zbyt silnych emocji, stresów i napięć rzadko najczęściej wskazywali respondenci ze starszych grup wiekowych - po 31 roku życia. Znacznie częściej udawało się to młodszym badanym.

W tabeli 3 przedstawiono wyniki średniej liczby punktów uzyskanych przez badanych w kategorii nawyki prozdrowotne. 
Tabela 3. Średnia liczba punktów uzyskanych przez badanych w kategorii nawyki prozdrowotne.

\begin{tabular}{|c|c|c|c|c|c|c|}
\hline Kategoria \\
zachowá́
\end{tabular}

Źródło: wynik badań własnych.

Jak wynika z tabeli 3 najtrudniej było przestrzegać nawyków prozdrowotnych osobom z przedziału wieku 31-35 lat oraz 41 i więcej. Respondenci w wieku 31-35 lat uzyskiwali bowiem najniższą średnią liczbę punktów za wystarczająco długie odpoczywanie (1,5 pkt.), w tym także spanie (1,75 pkt.) oraz kontrolowanie masy ciała i unikanie nadmiernego wysiłku fizycznego (po 2,75 pkt.). Jeden badany w wieku powyżej 41 lat także prezentował największe trudności $\mathrm{w}$ systematyczności stosowania powyższych nawyków prozdrowotnych.

W kategorii nawyki prozdrowotne respondenci uzyskali największą średnią liczbę punktów preferując takie zachowanie jak unikanie palenia tytoniu. Największa średnia liczba punktów w tym pytaniu wynosiła 5 i dotyczyła osób z przedziałów wiekowych: 31-35 lat, 36-40 lat oraz 41 i więcej lat. 
Najmniejszą średnią liczbę punktów studenci niezależnie od wieku otrzymali za wdrażanie takich zachowań jak unikanie przepracowania oraz wystarczająco długie odpoczywanie i sen. Najmniejszą średnią liczbę punktów za pytanie wystarczająco długie odpoczywanie uzyskał badany w wieku powyżej 41 lat (1 pkt.) oraz 31-35 lat (1,5 pkt.). W kategorii „unikam przepracowania” najmniejsza średnia liczba punktów dotyczyła osób w wieku 31-35 lat i 26 - 30 lat (po 2 pkt.) i respondenta powyżej 41 roku życia (1 pkt.). W najmniejszym zakresie wystarczająco dużo śpią badani w z przedziału wiekowego 31-35 lat (1,75 pkt.) oraz 41 i więcej lat (2 pkt.).

Analizę preferencji respondentów $\mathrm{z}$ uwzględnieniem przedziałów wiekowych $\mathrm{w}$ zakresie ograniczenia palenia tytoniu przedstawia rycina 4.

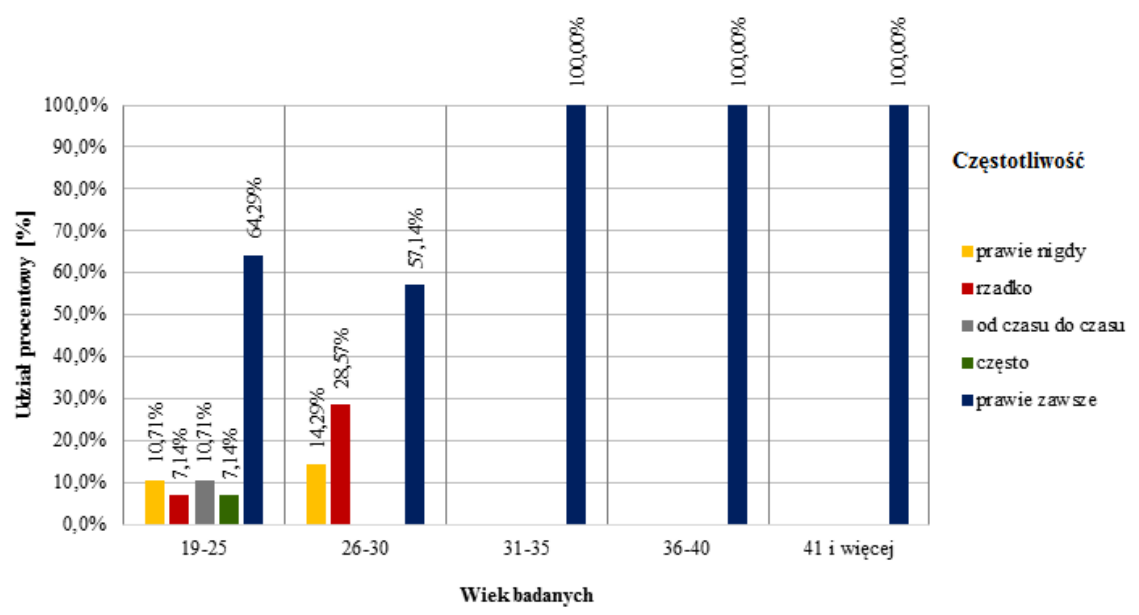

Rycina 4. Ograniczenie palenia tytoniu przez badanych w zależności od ich wieku.

Źródło: wynik badań własnych. 
Jak wynika $\mathrm{z}$ ryciny 4 największe zróżnicowanie zaobserwowano w odpowiedziach studentów w przedziale wiekowym 19-25 lat. Studenci w tym zakresie wieku prawie zawsze ograniczają palenie tytoniu $(64,29 \%)$ a zaledwie $10,71 \%$ tej grupy prawie nigdy tego nie robi. W przedziale wiekowym 26-30 lat ponad połowa studentów prawie zawsze redukuje palenie tytoniu $(57,14 \%)$, prawie nigdy tego nie robi $14,29 \%$ badanych. Wszyscy respondenci (odpowiednio po 100\%) w przedziałach wiekowych 31-35 lat , 36-40 lat oraz 41 i więcej (100\%) deklarują, że prawie zawsze ograniczają palenie tytoniu.

Analizę preferencji respondentów $\mathrm{z}$ uwzględnieniem przedziałów wiekowych $\mathrm{w}$ zakresie wystarczająco długiego odpoczynku przedstawia rycina 5 .

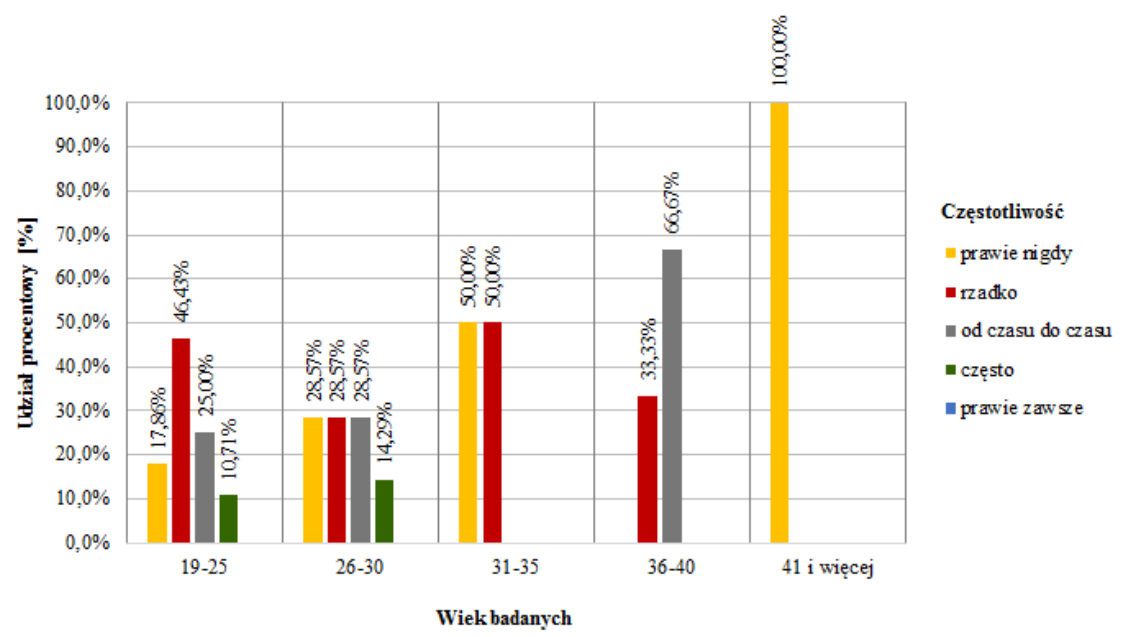

Rycina 5. Wystarczająco długi odpoczynek preferowany przez badanych w zależności od wieku.

Źródło: wynik badań własnych.

Jak wynika z ryciny 5 respondenci z przedziału wiekowego 195 lat najczęściej rzadko $(46,43 \%)$ oraz od czasu do czasu $(25,0 \%)$ wystarczająco długo odpoczywają. Prawie nigdy, rzadko oraz od czasu 
do czasu wypoczywa odpowiednio długo po $28,57 \%$ studentów z przedziału wiekowego $26-30$ lat a tylko 14,29\% osób czyni to często. Badani w wieku powyżej 31 roku życia deklarują najczęściej kłopoty w zagwarantowaniu odpowiednio długiego wypoczynku. Lepiej radziły sobie $\mathrm{z}$ takim zachowaniem osoby $\mathrm{z}$ młodszych kategorii wiekowych.

Analizę preferencji respondentów z uwzględnieniem przedziałów wiekowych $\mathrm{w}$ zakresie unikania przepracowania przedstawia rycina 6 .

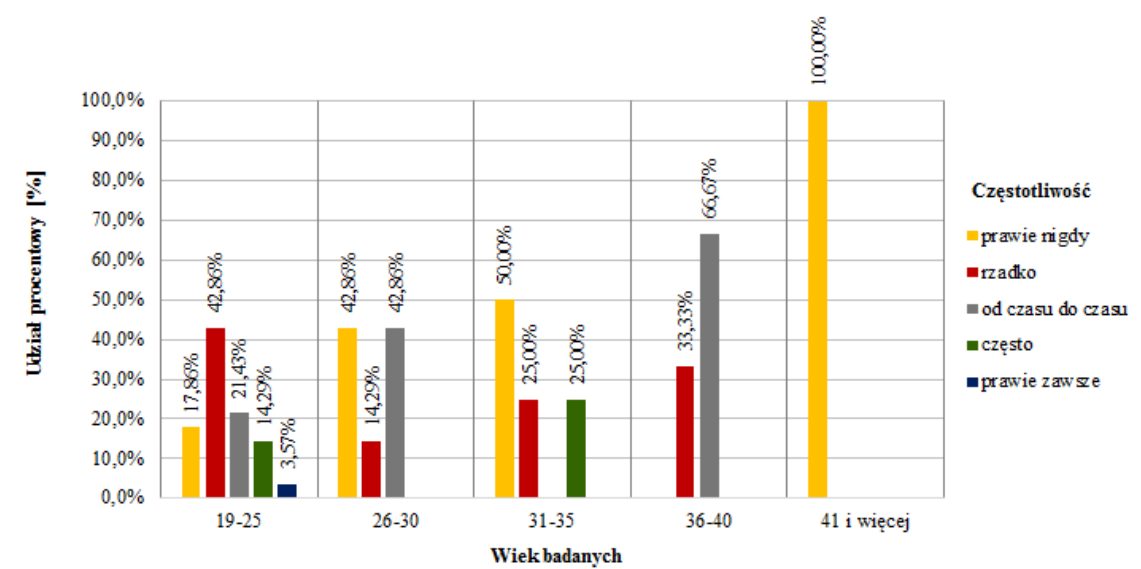

Rycina 6. Unikanie przepracowania przez badanych w zależności od ich wieku.

Źródło: wynik badań własnych.

Jak wynika z ryciny 6 niezależnie od wieku respondenci mieli kłopoty z unikaniem przepracowania. W przedziale wiekowym 19-25 lat $42,86 \%$ studentów odpowiedziało, że rzadko unika przepracowania, a tylko zaledwie $3,57 \%$ badanych prawie zawsze się to udaje. W przedziale wiekowym $26-30$ lat $42,86 \%$ respondentów prawie nigdy oraz od czasu do czasu unika przepracowania a z kolei tylko $14,29 \%$ badanych udaje się to rzadko. W przedziale wiekowym 31-35 lat prawie nigdy nie udaje się wdrożyć takiego zachowania 
połowie studentów (50,0\%). W przedziale wiekowym 36-40 lat od czasu do czasu aż 66,67\% studentów unika przepracowania. W przedziale wiekowym 41 i więcej jeden student (100\%) twierdził, że prawie nigdy unika przepracowania.

\section{Dyskusja}

Wyniki badań własnych z wykorzystaniem IZZ wskazują, że studenci kierunku pielęgniarstwo prezentują wprawdzie nieistotny statystycznie, ale zróżnicowany poziom nastawienia psychicznego jak i nawyków zdrowotnych. Ma on charakter stosunkowo satysfakcjonujący. Jest to dobry prognostyk wskazujący na dobre preferencje $w$ zakresie nastawienia psychicznego i zdrowia osób, które w ramach działań zawodowych będą propagować zdrowy styl życia wśród odbiorców świadczeń zdrowotnych [10]. Należy podkreślić, że zachowania prozdrowotne to bardzo aktualny trend, współcześnie szeroko propagowany przez profesjonalistów systemu ochrony zdrowia, ale także media; podkreślany w realizacji programów profilaktycznych i kampanii społecznych. Wpisany jest także w politykę zdrowotną państw.

Jak wynika $\mathrm{z}$ badań własnych respondenci najczęściej deklarowali preferowanie takich zachowań zdrowotnych jak: posiadanie przyjaciół i uregulowanego życia rodzinnego. W najmniejszym zakresie badani radzili sobie z unikaniem zbyt silnych emocji i napięć. Szczególnie pozytywnym elementem stylu życia jest unikanie palenia tytoniu przez studentów. Świadczyć to może o świadomości konsekwencji i negatywnych skutków uzależnienia od tytoniu, który jest czynnikiem ryzyka wielu chorób przewlekłych [11].

Ogólny wskaźnik nasilenia zachowań zdrowotnych badanej grupy studentów pielęgniarstwa określa się jednak jako przeciętny. W swoich badaniach Lewko $\mathrm{z}$ grupą współpracowników także w podobnej ocenie ten wskaźnik zachowań określili jako niski [12]. Podobny niski poziom niektórych zachowań zdrowotnych pielęgniarek 
(nieracjonalne żywienie, palenie tytoniu, występowanie nadwagi, dolegliwości psychiczne) potwierdzono $\mathrm{w}$ badaniach Muszalik i współautorów [13]. Analizując wyniki badań własnych zaobserwowano, że osoby w przedziale wiekowym 26-30 lat częściej prezentują zachowania antyzdrowotne np. sięganie po tytoń.

Niezależnie od wieku studenci najgorzej radzili sobie z takimi zachowaniami jak unikanie przepracowania i poświęcanie odpowiednio dużej ilości czasu na wypoczynek.

Studenci kierunku pielęgniarstwo w trakcie studiów doskonalą swoje kompetencje w zakresie promowania prawidłowych zachowań zdrowotnych. Z badań przedstawionych przez Muszalik wynika, że racjonalny tryb życia prowadzi 34,7\% pielęgniarek, natomiast znała i kontrolowała źródło stresu większość osób (84,9\%). Większość pielęgniarek $(85,8 \%)$ deklarowała, że uzyskuje w swoim środowisku rodzinnym wsparcie psychiczne w różnych sytuacjach trudnych [13].

Badania własne wykazały, że wiek nie wpływa istotnie na różnicę $\mathrm{w}$ zachowaniach zdrowotnych i nastawieniu psychicznym studentów. Zasadnym jest, aby preferencje prozdrowotne dotyczyły w pierwszej kolejności ich samych, ale także rodziny i osób w najbliższym otoczeniu, jako swoistej sieci wsparcia społecznego. Zmiany preferowanych zachowań zdrowotnych są bowiem możliwe [11]. Największe zróżnicowanie $\mathrm{w}$ preferowanych zachowaniach zdrowotnych obserwuje się wśród najmłodszych studentów w wieku 19 -25 lat.

Przeprowadzone badania własne oraz badania innych autorów pokazują, że nastawienie psychiczne i nawyki żywieniowe są uwarunkowane wiekiem. Występuje znaczące zróżnicowanie w nastawieniu psychicznym i nawykach prozdrowotnych: obecnie są tu zarówno postawy prozdrowotne jak i zachowania w negatywny sposób wpływające na stan zdrowia studentów kierunku pielęgniarstwo. Niezbędne jest promowanie wśród nich poczucia odpowiedzialności za własne zdrowie, samopoczucie i życie. Buławska wskazuje, iż zależy to od ich wiedzy, postawy oraz poziomu motywacji, 
które stanowią niezbędne czynniki dla kształtowania i utrzymania zachowań sprzyjających zdrowiu [14].

\section{Wnioski}

Badania wykazały, że wiek nie wpływa istotnie na różnicę w zachowaniach zdrowotnych i nastawieniu psychicznym studentów. Największe zróżnicowanie $\mathrm{w}$ preferowanych zachowaniach zdrowotnych obserwuje się wśród najmłodszej grupy studentów w wieku 19 - 25 lat.

Wiek nie wpływa istotnie na różnice w nastawieniu psychicznym. Niezależnie od kategorii wiekowej badani podkreślali posiadanie przyjaciół i uregulowanego życia rodzinnego. W najmniejszym zakresie respondenci radzili sobie z unikaniem zbyt silnych emocji i napięć.

Niezależnie od wieku respondenci uzyskiwali największą liczbę punktów w kategorii zachowania zdrowotne. Najmniejsza punktacja dotyczyła badanych w przedziale wiekowym 26-30 lat, co może świadczyć o częstej prezentacji zachowań antyzdrowotnych.

Niezależnie od wieku studenci najgorzej radzili sobie z takimi zachowaniami jak unikanie przepracowania i poświęcanie odpowiednio dużo ilości czasu na wypoczynek.

\section{Zalecenia dla praktyki pielęgniarskiej}

Przeprowadzone badania dają możliwość wykorzystania wyników bezpośrednio w praktyce pielęgniarskiej w odniesieniu do nowych adeptów zawodu. Może to służyć redukcji zachowań antyzdrowotnych a stymulować zachowania prozdrowotne.

\section{Bibliografia/Bibliography:}


1. Siciński A. (red), Styl życia: koncepcje i propozycje. Państwowe Wydawnictwo Naukowe. Warszawa 1976.

2. http://interklasa.pl/portal/dokumenty/zdrowie/11.html(dostęp: 16.02.2017r.)

3. Binkowska - Bury M., Marć M., Januszewski P. Wiedza o zdrowiu a zachowania ryzykowne $\mathrm{w}$ środowisku młodzieży akademickiej. Medycyna Ogólna. 2010;16(XLV),1:100 - 112.

4. http://www.izz.waw.pl/pl/zasady-prawidowego-ywienia (dostęp: 17.02.2017r.)

5. Woynarowska B. Edukacja Zdrowotna. Wydawnictwo Naukowe PWN. Warszawa 2007.

6. Baranowicz I., Majchrowska A., Kawczyńska-Butrym.: Elementy socjologii dla pielęgniarek. Wydawnictwo Czelej. Lublin 2000.

7. Markowski A. (red), Słownik wyrazów obcych i trudnych. Wyd. WILGA. Warszawa 2003;318.

8. Heszen I., Sęk H. Psychologia zdrowia. Wydawnictwo Naukowe PWN. Warszawa 2007.

9. Juczyński Z. Narzędzia pomiaru w promocji i psychologii zdrowia. Pracownia Testów Psychologicznych, Warszawa 2009.

10. Cymes M., Andrzejewska M., Nowicki M., Kałos U., Klimczak M. Nawyki żywieniowe lekarzy oraz osób z wyższym wykształceniem niemedycznym - analiza porównawcza. Endokrynol Otyłość. 2009;5(3):141-142.

11. Rasińska R., Nowakowska I. Palenie tytoniu wśród studentów porównanie badań własnych $\mathrm{z}$ literaturami. Przegl Lek. 2012;69(10):888-892. 
12. Lewko J., Polityńska-Lewko B., Sierakowska M., Krajewska-Kułak E. Zachowania zdrowotne wśród studentów pielęgniarstwa. Ann. Univ. Mariae. Curie. Sklodowska. (Med.) 2005;60(16,3):260-264

13. Muszalik M., Kędziora-Kornatowsk K., Marzec A., Klawe J. Analiza zachowań zdrowotnych, samooceny oraz zagro- żeń zdrowia pielęgniarek studiujących zaocznie. Probl. Hig. Epidemiol. 2007;88(3):354-359.

14. Buławska K. Wartość zdrowia a zachowania zdrowotne młodzieży. Sztuka Leczenia. 2001;7(4):57-61. 